\title{
DIVERSITY AND NUMBER OF WOODPECKERS (PICIDAE) IN THE CHUVASH TRANS-VOLGA REGION IN WINTER
}

\author{
(C) 2018
}

Kolenov Sergei Evgenievich, postgraduate student, engineer of Zoology and General Biology Department Kazan (Volga Region) Federal University (Kazan, Russian Federation)

\begin{abstract}
This article gives some data on the winter fauna of woodpeckers (Picidae) in the Trans-Volga Region of the Chuvash Republic. We analyze the species richness, their number and trends of its changes. To do it, it is possible when the reserachers analyze the results of the collected materials of 2010-2018 (on the example of three routes during ornithological surveys according Y.S. Ravkin's method). The author believes that the importance of work is to show the lack of surveys concerning the analysis of winter fauna of woodpeckers in the Chuvash Trans-Volga Region. Moreover it shows to determine what impact on the avifauna of the Transvolga was caused by destructive fires in the summer of 2010 (as it destroyed up to $30 \%$ of the forest cover of the investigated territory). The article presents that the Chuvash Trans-Volga Region is inhabited by 6 species of woodpeckers out of 9, named in the Chuvash Republic. A great spotted woodpecker was a numerous and dominant species, black woodpecker was ordinary species, and the rest were less common. The greatest variety of woodpeckers was noted on the route with the maximum variety of vegetation and plenty of dead wood. A reliable positive population trend was revealed for the black woodpecker. The population of the great spotted woodpecker as a whole remained stable although it showed considerable fluctuations from year to year, depending on the yield of coniferous trees. For other species, it was not possible to identify any long-term trend. Three species of woodpeckers (the black, the lesser spotted and the three-toed woodpeckers) demonstrated mutual changes of the average winter density. All these species showed a significant increase in numbers, which gave a way to a decline then. We believe that the growth in numbers was due to the fires and drought of 2010, which provoked an outbreak of xylophagous insects and fodder base of these species. The subsequent clearing of the burners and the sanitary cutting reduced the food resources available for insects, what decrease the number of woodpeckers. We believe that sanitary cuttings should be abandoned in some areas of the Trans-Volga Region to preserve these species.

Keywords: woodpeckers; Piciformes; great spotted woodpecker; black woodpecker; three-toed woodpecker; lesser spotted woodpecker; grey-headed woodpecker; white-backed woodpecker; green woodpecker; middle spotted woodpecker; wryneck; winter population of birds; dynamics of number of birds; ecology; coniferous forests; Chuvash Republic; Cheboksary district; Volga Region; Chuvash Trans-Volga Region; wildfires.
\end{abstract}

УДК 582.263, 574.34, 582.293.346

Статья поступила в редакцию 02.07.2018

\section{ВИДОВОЕ РАЗНООБРАЗИЕ И ОСОБЕННОСТИ ЛОКАЛИЗАЦИИ ФОТОБИОНТА В ЭПИГЕЙНЫХ ЛИШАЙНИКАХ РОДА CLADONIA}

(C) 2018

Корчиков Евгений Сергеевич, кандидат биологических наук, доцент кафедры экологии, ботаники и охраны природы

Болгов Егор Владимирович, студент биологического факультета

Ильина Елена Сергеевна, студент биологического факультета

Самарский национальный исследовательский университет имени академика С.П. Королёва

(2. Самара, Российская Федераиия)

Панкратов Тимофей Анатольевич, кандидат биологических наук, руководитель проекта, кафедра биологии почв

Московский государственный университет им. М.В. Ломоносова (2. Москва, Российская Федерация)

Аннотаиия. В данной статье рассматривается таксономический состав и особенности локализации фотобионтов в кустистых эпигейных лишайниках рода Cladonia. Описываются количество и видовая принадлежность клеток водорослей в гомогенатах талломов в зависимости от их возраста: в зонах активного роста, старения и разложения, а также в смывах с талломов. Рассматривается влияние микобионта на видовой состав и численность фотобионта. Приводится сравнение этих данных в лишайниках северотаёжной зоны (Мурманская область) и степной зоны (Оренбургская область). Определение таксономической принадлежности фотобионтов к роду определяли методом прямой микроскопии с использованием морфологических критериев: размер, форма клеток, характер хроматофора и т.п. Численность фотобионта в образцах исследовали как методом световой микроскопии, так и с помощью флуоресцентной микроскопии. В работе представлены результаты сравнения численности и разнообразия водорослей в талломах эпигейных лишайников рода Cladonia в зависимости от их географической локализации и характера возрастной динамики подециев. Проведённые исследования показали, что доминирующими группами в активно растущих подециях лишайников были представители рода Asterochloris вне зависимости от их географической локализации. В лишайниках обнаружены представители родов Chlorella, Stichococcus, Pseudococcomyха. Новыми для науки оказались сведения об изменении таксономического состава водорослей в зависимости от возраста таллома: в старых частях северотаёжных лишайников доминировали водоросли Pseudococcomyха, а в степных - Stichococcus. Сделана попытка ресинтеза лишайникового таллома из ранее изолированных культур микобионта и фотобионта. На данном этапе исследований она оказалась неудачной. 
Ключевые слова: симбиотические организмы; фотобионт; Asterochloris; Stichococcus; Chlorella; Pseudococcoтуха; микробные сообщества лишайников; таксономическая структура симбиозов; динамика численности водорослей; северотаёжная зона; степная зона; ББС МГУ; Мурманская область; Оренбургская область.

\section{Введение}

Лишайники согласно классическому определению - это симбиотические организмы, существующие в результате мутуалистического взаимодействия гетеротрофного (грибного) и фототрофного (водоросли или цианобактерии) компонентов. В некоторых источниках лишайниковый симбиоз рассматривается как паразитизм гриба на водоросли. Несмотря на давнюю историю исследований лишайников особенности динамики численности и таксономической структуры населяющих их микроорганизмов не были предметом пристального изучения. Только в последние два десятилетия, в связи с развитием молекулярно-биологических методов исследований удалось обнаружить в лишайниках не только микобионт и фотобионт, но также и целый комплекс сопутствующих видов грибов, водорослей, а также бактериосимбионтов и простейших (Т.А. Панкратов и др. [1]). Некоторые особенности распределения и таксономической структуры бактерий и грибов в лишайниках исследованы зарубежными $[2 ; 3]$ и российскими исследователями [4-6]. Хотя данные о таксономическом составе фотобионтов в талломах неплохо представлены в научных публикациях [7], количественных данных об их распределении внутри талломов в литературе почти нет.

Целью работы было изучение таксономического состава и численности водорослей в талломах лишайников, собранных на территории Беломорской биостанции (ББС) МГУ, в горном массиве Хибины (Мурманская область) и в Оренбургской области. Особое внимание было уделено исследованию динамики изменения состава и численности клеток водорослей в зависимости от возраста таллома. В соответствии с целью были поставлены следующие задачи: 1) провести идентификацию водорослей в растущей (верхушечной) и деградирующей (нижней) частях подециев эпигейных лишайников рода Cladonia; 2) установить численность морфотипов (видов) в подециях в зависимости от их локализации; 3) сравнить данные о таксономическом составе и численности водорослей в лишайниках северотаёжной и степной зон; 4) выделить в чистые культуры водоросли идентифицированных видов и попытаться провести ресинтез лишайников.

\section{Материалы и методы исследования}

Для анализа были отобраны образцы эпигейных лишайников следующих видов: Cladonia arbuscula (Wallr.) Flot. ssp. arbuscula, C. stellaris (Opiz.) Brodo (Cladonia alpestris (L.) Rabenh.), C. rangiferina (L.) Weber ex F.H. Wigg., которые произрастали в хвойных сообществах Мурманской области и Хибинах (ельники), и Оренбургской области (сосняки на территории национального парка «Бузулукский бор»). Все три вида относятся к кустистым кустисторазветвлённым [8-11].

Образцы лишайников сразу же после сбора высушивали, затем до проведения экспериментов хранили в холодильнике при температуре $+5^{\circ} \mathrm{C}$. Далее образцы гомогенизировали растиранием в фарфоро- вой ступке или с использованием гомогенизатора IKA Ultra-Turrax Tube Drive аналогично применённой ранее методике [6]. Учёт численности проводили в 30-ти полях зрения при увеличении $\times 1000$ на микроскопах Микмед-6 и Микромед 3 ЛЮМ. Выделение водорослей в чистые культуры проводили с использованием гомогенатов подециев. Культивировали на среде ВВМ [12] при температуре $+15^{\circ} \mathrm{C}$ и освещённости 3500 лк. Определение фотобионтов проводили по определителям [13; 14].

Для выявления необходимых для лишайникового симбиоза фотобионтов проводили следующий эксперимент. На плотную среду Кнопа с долей агара $2 \%$ наносили в стерильных условиях чистую культуру микобионта в четырёх местах на чашки Петри. Затем туда же добавляли культуру фотобионта в следующих сочетаниях: Chlorella sp.; Chlorella sp. + Asterochloris sp.; Chlorella sp. + Asterochloris sp. + Stichococcus sp. Данный эксперимент проводили в пятикратной повторности с Cladonia arbuscula и C. stellaris. В первые четыре месяца эксперимента осуществляли еженедельный полив стерильной водой по 1 капле.

Статистическая обработка результатов была произведена с помощью Microsoft Excel 2010.

\section{Результаты исследований и их обсуждение}

Анализ тотальных гомогенатов лишайников показал наличие в них четырёх основных морфотипов клеток водорослей, три из которых были идентифицированы на основании морфологических и культуральных характеристик (рис. 1). Попытки изолировать эти водоросли в чистые культуры привели к выделению в аксенически чистую культуру только водорослей рода Pseudococcomyxa, тогда как Chlorella, Stichococcus и Asterochloris очистить от бактериальных спутников не удалось.

Главная закономерность, которая прослеживалась во всех видах лишайников обеих географических зон - доминирование водорослей рода Asterochloris в верхушечной, активно растущей зоне подециев. Особенно хорошо это заметно в лишайниках из степной зоны, в частности C. arbuscula (рис. 2), в которых численность клеток водорослей этого рода достигала уровня $6 \cdot 10^{7}$ кл/г, в то время как в северотаёжных лишайниках численность была не выше $3 \cdot 10^{7}$ кл/г. Это можно объяснить более высокими потребностями микобионта в органических веществах на фоне значительно более высоких температур вегетационного периода, а также значительным уровнем инсоляции в степной зоне.

При анализе количественных данных в лишайниках северотаёжной зоны выявлена закономерность: доминирование водорослей Asterochloris в верхушечной части лишайников C. arbuscula, C. rangiferina и C. stellaris сменяется равномерным распределением клеток двух видов фотобионтов, а в стареющих частях и на стадии разложения таллома начинают доминировать водоросли рода Pseudococcomуха. Недавно водоросли рода Pseudococcomyха и Stichococcus были обнаружены в почве Мурманской области под лишайниками рода Cladonia [15]. 

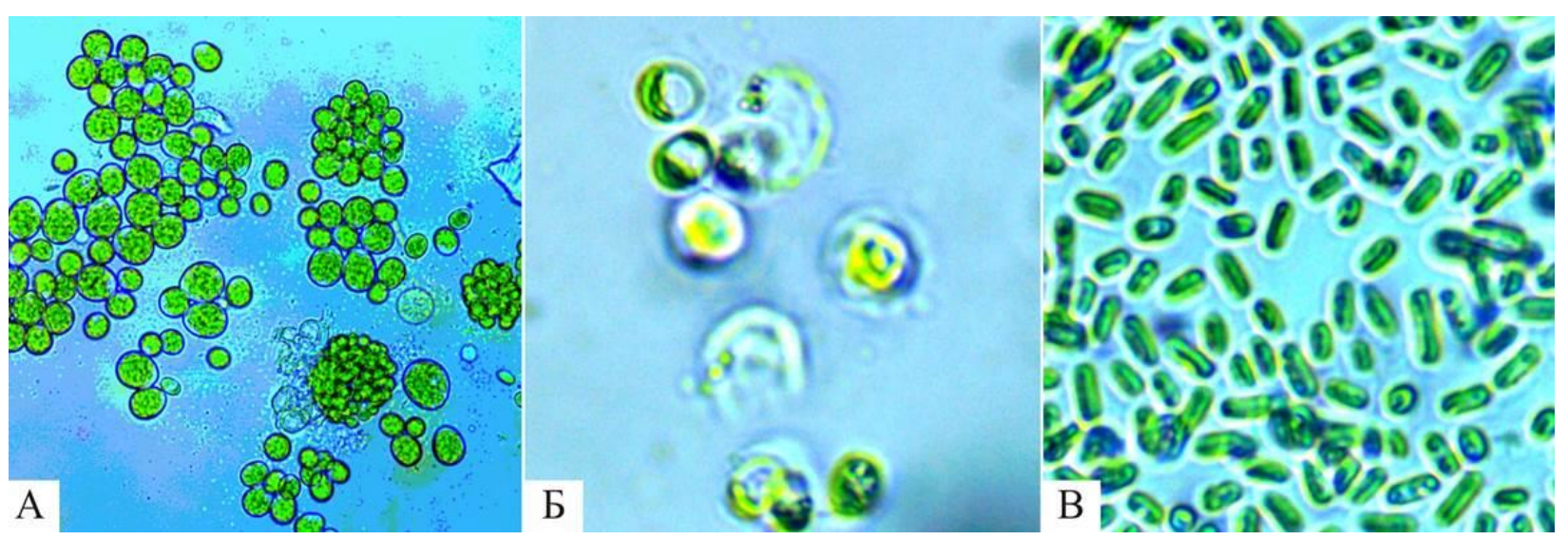

Рисунок 1 - Микрофотографии культур фотобионтов из лишайника Cladonia arbuscula, произрастающего в Оренбургской области: $A-$ Asterochloris sp.; $E$-Chlorella sp.; $B$ - Stichococcus sp. Увеличение $\times 280(A), \times 400(Б, B)$

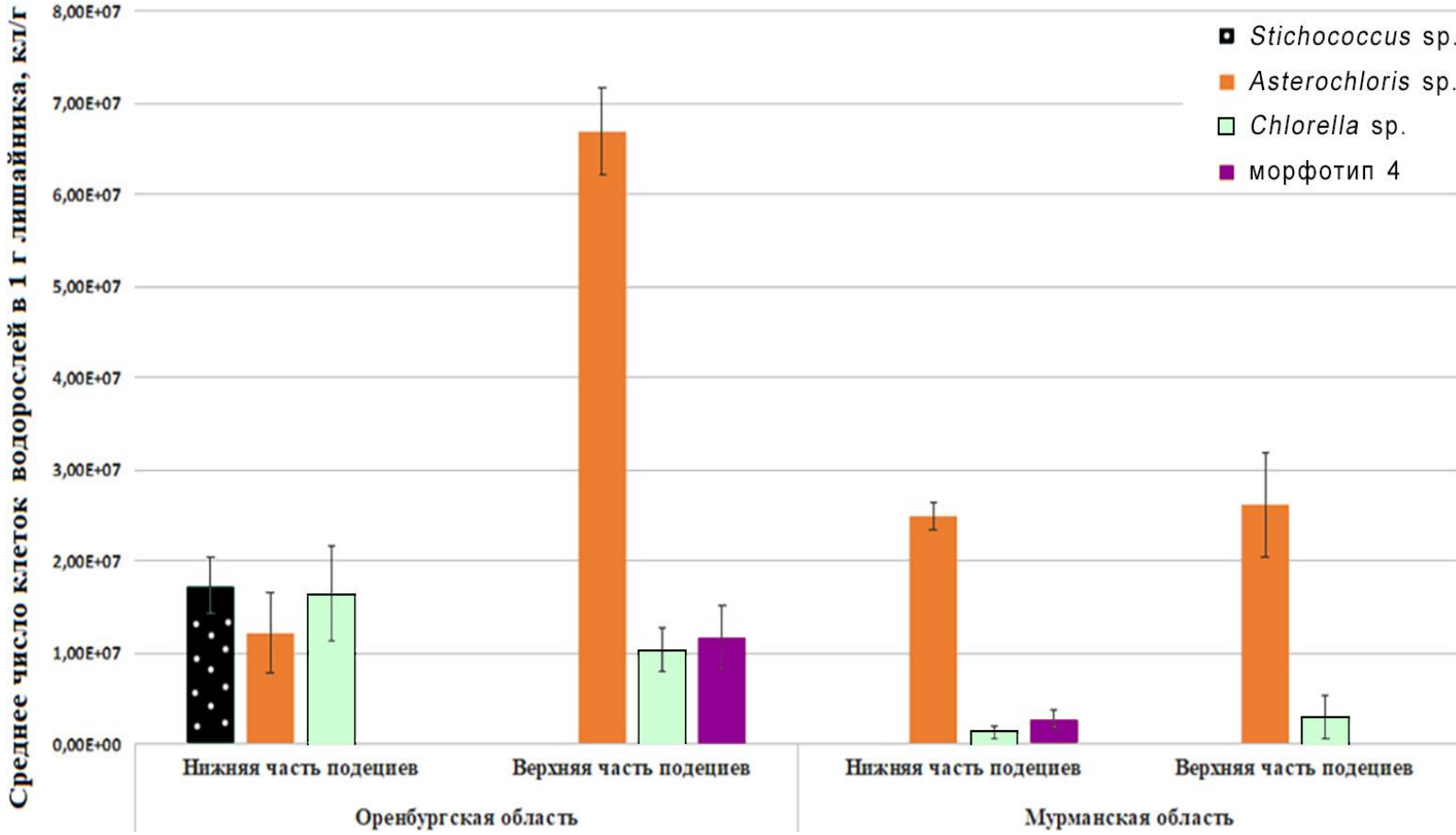

Рисунок 2 - Число клеток водорослей разных функциональных зон эпигейного лишайника Cladonia arbuscula, произрастающего в разных природных зонах

Наличие неидентифицированной водоросли в составе разных участков талломов лишайников обеих географических зон (рис. 2) указывает на вероятную зависимость активности этого морфотипа от климатических условий. В степной зоне он проявляет себя как один из компонентов активно растущего таллома, а в северотаёжной субарктической - как компонент микробного сообщества лишайника на стадии его деградации. Полученные нами данные на основании прямого анализа с помощью световой микроскопии диссонируют с таковыми, полученными Р. Моуа [16] в 2017 году методом анализа геномной ДНК, выделенной из лишайника $R$. farinacea. Авторы этой публикации обнаружили увеличение численности OTU (операционных таксономических единиц), принадлежащих Asterochloris spp. и прочим зелёным водорослям от апикальной к базальной части таллома. И напротив, количество ОТU, относящихся к Trebouxia spp. снижалось. Отличие в полученных peзультатах может быть объяснено как применением разных методов оценки численности, а также видовой и экологической разницей изучаемых лишайни- ков. Лишайники рода Ramalina - в основном эпифитные, растущие на коре деревьев, тогда как представители рода Cladonia - это, главным образом, эпигейные виды, нижняя часть подециев которых взаимодействует с субстратом (как правило, почвой). К сожалению, в научной литературе отсутствуют сведения о молекулярно-генетическом анализе данных о распределении водорослей в лишайниках рода Cladonia, что не позволяет провести сравнения наших результатов с данными других исследователей. Кроме того, только в одной статье [17] приведены различия географического характера для лишайников Индии и Непала. Однако в этой публикации рассматриваются только водоросли рода Asterochloris.

Существует и ещё один аспект: характер расположения микроколоний водорослей в лишайнике. Не исключено, что вторичные виды водорослей локализованы не в слое фотобионта лишайников, а на поверхности талломов, в микролокусах, не отделяющихся полностью от таллома при промывке проточной водой. Поэтому роль их как истинных фотобионтов можно поставить под сомнение. 
В изученной литературе нет данных о способе подготовки материалов для анализа. Возможно, что выделение геномной ДНК и приготовление тотальных препаратов гомогенатов для оптической микроскопии проводилось без предварительной отмывки талломов. В нашей работе метод гомогенизации в фарфоровой ступке был дополнен более сложным способом подготовки образца: мы провели предварительную отмывку талломов лишайников C. rangiferina и $C$. arbuscula из Оренбургской и Мурманской областей с использованием вортекса Multi Reax (Heidolph, Германия). Последующую промывку проводили методом прессования в шприце, снабжённом фильтрующим ватным диском, с трёхкратной промывкой фосфатным буфером. Затем промытый и измельчённый таллом гомогенизировали до однородной суспензии с использованием гомогенизатора IKA Ultra-Turrax Tube Drive. Полученные данные приведены на рисунке 3.

Для гомогенатов отмытых талломов в целом характерна сходная динамика изменения численности Asterochloris, как и в случае растирания талломов в ступке. Однако выявлена несколько бо́льшая численность этого фотобионта в растущих частях $C$. arbuscula $-2 \cdot 10^{8}$ кл/г, что можно связать с механическим повреждением крупных клеток в процессе растира- ния, в отличие от более мягкого метода роторной гомогенизации. В апикальной зоне $C$. rangiferina число клеток Asterochloris было около 5,5·10 $0^{7}$ кл/г. В отличие от первого метода, в отмытых гомогенатах степных лишайников численность водорослей-спутников была ниже, достигая значений $10^{6}$ кл/г. В зрелой (серединной) зоне подециев численность основного фотобионта снижалась почти на порядок, в базальной части доходила до $3 \cdot 10^{7}$ кл/г в C. rangiferina и $9 \cdot 10^{6}$ кл/г в C. arbuscula. В смывах с талломов данных лишайников живых водорослей рода Asterochloris не было обнаружено, но встречались клетки других водорослей. Также наличие оболочек клеток основного фотобионта в смывах может свидетельствовать об их присутствии на поверхности талломов, где их жизнеспособность теряется.

Динамика изменения численности фотобионтов в образцах лишайников из Мурманской области, Хибин и Оренбургской области в целом остается такой же. Наименьшая абсолютная численность Asterochloris минимальна в образцах лишайника C. arbuscula, отобранных на территории ББС МГУ (сфагновое болото), а максимальна - в образцах из Бузулукского бора, средние значения демонстрируют образцы, собранные в горных экосистемах Хибин (рис. 3).

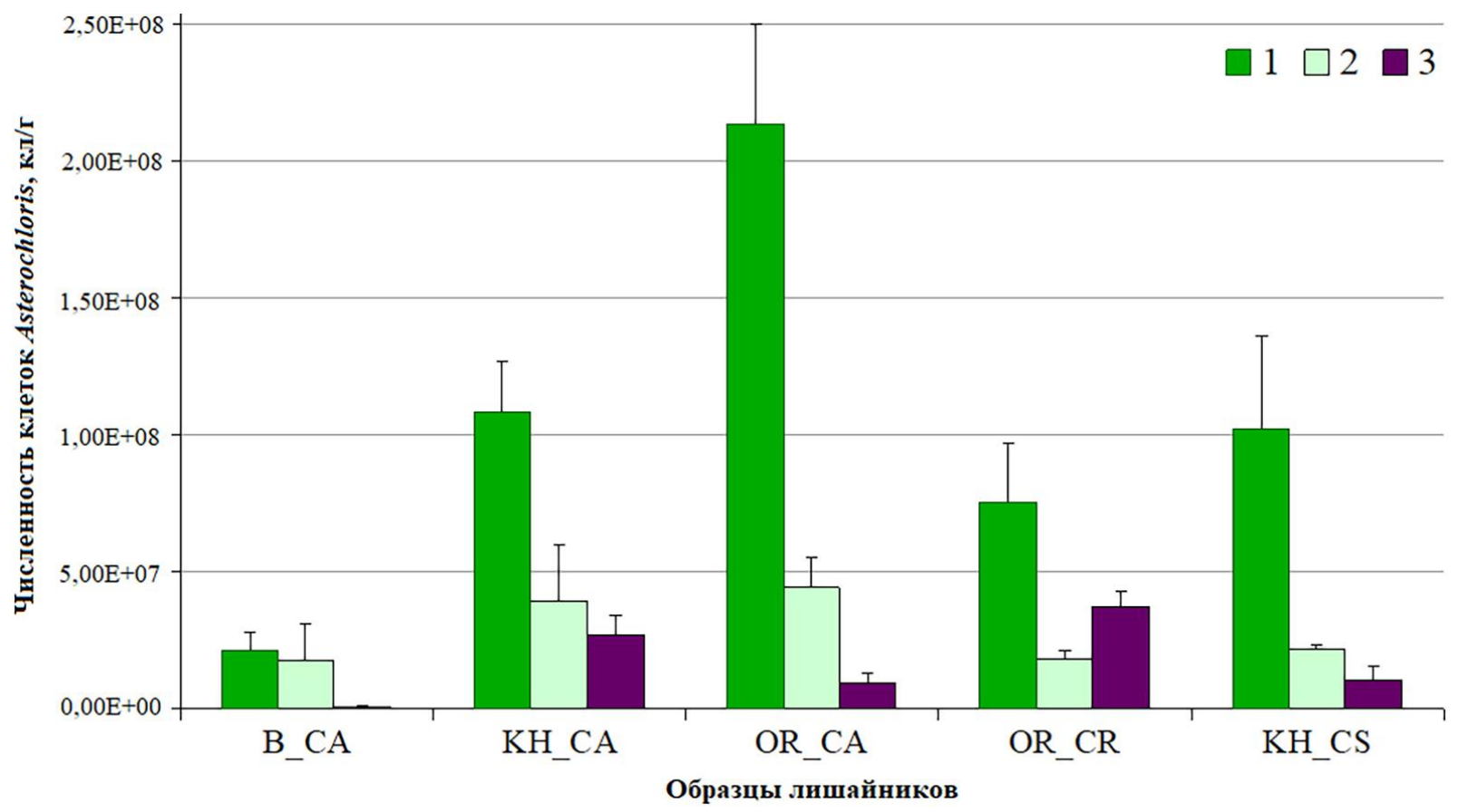

Рисунок 3 - Динамика изменения численности фотобионта рода Asterochloris в лишайниках C. arbuscula (CA) Оренбургской области $(O R)$, Хибин $(K H)$ и Биологической станции МГУ (Мурманская область) (B); C. rangiferina $(C R)$ и C. stellaris (CS): 1 - верхушка, 2- середина, 3- базальная часть подециев

В ряде образцов лишайников из Мурманского региона в гомогенатах верхушечных частей $C$. rangiferina наряду с главным фотобионтом присутствовали клетки Pseudococcomyxa. Количество этих клеток увеличивалось пропорционально степени деструкции таллома (данные не показаны).

В смывах с поверхности талломов всех изученных образцов лишайников были найдены единичные клетки Asterochloris, Stichococcus, Pseudococcomyха и Chlorella, их численность не превышала $10^{4}$ кл/г.

Интерпретация полученных количественных данных на данном этапе исследований вызывает затруднения. Однако можно с уверенностью говорить, что в молодых (апикальных) зонах подециев эпигейных лишайников рода Cladonia интенсивность размножения водорослей Asterochloris обусловлена большей физиологической активностью микобионта, так как объяснить полученные результаты с позиций интенсивности минерального питания сложно. Кроме того, у нас уже имеются данные о присутствии в талломах лишайников эндофитных бактерий, большая часть которых принадлежит порядку Rhizobiales. Среди бактерий этого порядка присутствуют и виды, способные к азотфиксации. Ряд выделенных из лишайников микроорганизмов способны солюбилизировать фосфаты. 
Также нами была предпринята попытка совместить ранее полученные чистые культуры микобионта и фотобионта лишайников C. arbuscula и C. stellaris для ресинтеза талломов. В лабораторных условиях водоросли рода Asterochloris более активно развивались при температуре $+15^{\circ} \mathrm{C}$, в то время как другие зелёные водоросли лучше росли при более высоких температурах.

Первая серия экспериментов проведена с микобионтом Cladonia stellaris. Оказалось, что при выбранных условиях культивирования клетки водорослей росли намного лучше, чем мицелий микобионта, образуя пятна по размеру растекающейся капли при еженедельном увлажнении и толщиной до 1 мм.

Микроскопия всех вариантов эксперимента с тремя видами водорослей через 6,5 месяцев показала доминирование Stichococcus sp., образующий цепочки из трёх клеток длиной до 12,5 мкм при толщине идовое разнообразие и особенности локализации фотобионта...

2,5 мкм, но иногда встречались клетки Asterochloris sp. и Chorella sp. Следовательно, именно Stichococcus sp. является in vitro более конкурентоспособным среди остальных видов водорослей. Возможно, ему помогает занять лидирующее положение обильная слизистая оболочка, во много раз превышающая его размеры, что способствует вытеснению других видов.

Культура Stichococcus sp. из-за продуцируемой ею слизи обволакивала чешуйки микобионта и препятствовала другим видам фотобионта вступить в контакт с грибом. Однако в одной из чашек был обнаружен образец, где на чешуйках микобионта ещё сохранились скопления клеток Asterochloris sp., находившиеся, однако, в угнетённом состоянии размером до 7,5 мкм. В этом же образце с Asterochloris наблюдалось ветвление чешуек микобионта беловатого цвета, растущее вверх как подеций (рис. 4).
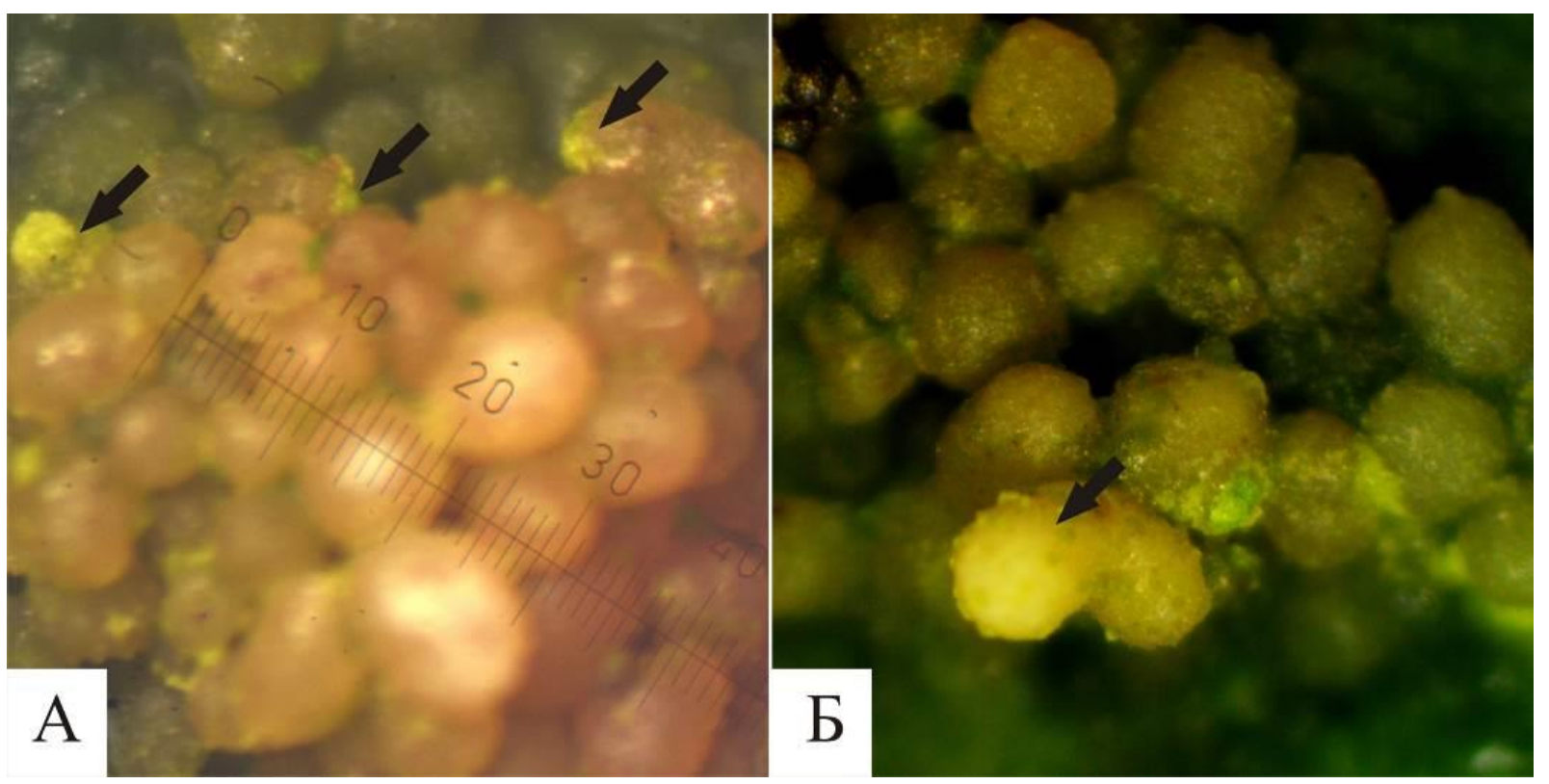

Рисунок 4 - Чешуйки микобионта Cladonia alpestris.

$A$ - Asterochloris sp. на чешуйках; 5 - ветвление чешуек, напоминающее подеций $(\times 14)$

Эксперименты с Cladonia arbuscula показали сходные результаты. Также отмечено преобладание во всех вариантах Stichococcus sp. и Chlorella sp., которые практически полностью вытеснили Asterochloris sp. Скорее всего, для воссоздания in vitro лишайникового симбиоза необходимы водоросли рода Asterochloris и микобионт, а также какие-то специфические факторы регуляции этого процесса. Подтверждением этой гипотезы служат литературные данные, в которых у лишайников рода Cladonia обнаруживается только один род фотобионта - Asterochloris [18-21]. Возможно, выявленные нами Chlorella sp. и Stichococcus sp. располагаются в разных функциональных зонах лишайника, предположительно в нижней части подециев. Об этом косвенно указывают результаты Патрисии Мойя с сотрудниками [16]. Их роль как фотобионтов пока трудно подтвердить, так как прямые исследования показывают их вторичное распространение в талломах исследованных лишайников. Доказательство их «фотобионтных» свойств можно получить только в процессе успешного моделирования (ресинтеза) лишайника с участием этих родов водорослей.

\section{Список литературы:}

1. Панкратов Т.А., Качалкин А.В., Корчиков Е.С., Добровольская Т.Г. Микробные сообщества лишайников // Микробиология. 2017. Т. 86, № 3. С. 1-19.

2. Grube M., Berg G. Microbial consortia of bacteria and fungi with focus on the lichen symbiosis // Fungal Biology Reviews. 2009. Vol. 23. P. 72-85.

3. Bates S.T., Cropsey G.W.G., Caporaso J.G., Knight R., Fierer N. Bacterial communities associated with the lichen symbiosis // Appl. and Environ. Microbiol. 2011. Vol. 77 (4). P. 1309-1314.

4. Паносян А.К., Никогосян В.Г. Очерк микрофлоры лишайников Армении // Биологический журнал Армении. 1969. Т. 22, № 1. С. 3-10.

5. Качалкин А.В., Глушакова А.М., Панкратов Т.А. Дрожжевое население лишайников полуострова Киндо // Микробиология. 2017. Т. 86, № 6. С. 762-769.

6. Панкратов Т.А. Бактериальные комплексы лишайников Хибин на примере Cladonia uncialis, C. portentosa, Alectoria ochroleuca, и Nephroma arcticum // Микробиология. 2018. Т. 87, № 1. С. 70-78.

7. Ruprecht U., Brunauer G., Türk R. High photobiont diversity in the common European soil crust lichen 
Psora decipiens // Biodiversity and Conservation. 2014. Vol. 23. P. 1771-1785.

8. Определитель лишайников СССР. Кладониевые и акароспоровые / под ред. И.И. Абрамова. Л.: Наука, 1978. Вып. 5. 304 с.

9. Сонина А.В., Степанова В.И., Тарасова В.Н. Лишайники. Морфология, анатомия, систематика. Петрозаводск: ПетрГУ, 2006. Ч. 1. 216 с.

10. Голубкова Н.С. Анализ флоры лишайников Монголии. Л.: Наука, 1983. 248 с.

11. Голубкова Н.С., Бязров Л.Г. Жизненные формы лишайников и лихеносинузий // Бот. журн. 1989. Т. 74, № 6. С. 794-804.

12. Protocols in lichenology culturing, biochemistry, ecophysiology and use in biomonitoring / ed. by I. Kranner, R. Beckett, A. Varma. Heidelberg: Springer, 2002. $46 \mathrm{p}$.

13. Мошкова Н.А., Голлербах М.М. Определитель пресноводных водорослей СССР. Зелёные водоросли. Класс улотриксовые. Л.: Наука, 1986. Вып. 10 (1). $360 \mathrm{c.}$

14. Андреева В.М. Почвенные и аэрофильные зеленые водоросли (Chlophyta: Tetrasporales, Chlorococcales, Chlorosarcinales). СПб.: Наука, 1998. 349 с.

15. Корнейкова М.В., Редькина В.В., Шалыгина Р.Р. Альго-микологическая характеристика почв в сосновом и березовом лесах на территории заповедника «Пасвик» // Почвоведение. 2018. № 2. С. 211-220.

16. Moya P., Molins A., Martínez-Alberola F., Muggia L., Barreno E. Unexpected associated microalgal di- versity in the lichen Ramalina farinacea is uncovered by pyrosequencing analyses // PLoS ONE, 2017. Vol. 12, № 4. P. 1-21.

17. Ř́dká T., Peksa O., Rai H., Upreti D.K., Škaloud P. Photobiont diversity in Indian Cladonia lichens, with special emphasis on the geographical patterns // Terricolous lichens in India. New York: Springer, 2014. P. 53-71.

18. Жизнь растений. Водоросли и лишайники / под ред. М.М. Голлербаха. М.: Просвещение, 1977. Т. 3. С. 378-487.

19. Шапиро И.А. Загадки растения-сфинкса. Лишайники и экологический мониторинг. Л.: Гидрометеоиздат, $1991.96 \mathrm{c.}$

20. Assembling the challenging puzzle of algal biodiversity: species delimitation within the genus Asterochloris (Trebouxiophyceae, Chlorophyta) / P. Skaloud, J. Steinova, T. Ridka [et al.] // J. Phycol. 2015. Vol. 51. P. 507-527.

21. Moya P., Škaloud P., Chiva S., Francisco J. García-Breijo F.J., Reig-Arminnana J., Vančurová L., Barreno E. Molecular phylogeny and ultrastructure of the lichen microalga Asterochloris mediterranea sp. nov. from Mediterranean and Canary islands ecosystems // International Journal of Systematic and Evolutionary Microbiology. 2015. Vol. 65. P. 1838-1854.

Работа выполнена при поддержке Российского фонда фундаментальных исследований (проект № 16-04-00966a).

\section{SPECIES DIVERSITY AND PHOTOBIONT LOCALIZATION SPECIFICITIES IN EPIGENE LICHENS (ON THE EXAMPLE OF THE GENUS CLADONIA)}

(C) 2018

Korchikov Evgene Sergeevich, candidate of biological sciences, associate professor of Ecology, Botany and Nature Protection Department

Bolgov Egor Vladimirovich, student of Biology Faculty

Ilyina Elena Sergeevna, student of Biology Faculty

Samara National Research University (Samara, Russian Federation)

Pankratov Timofey Anatolyevich, candidate of biological sciences, project supervisor, Soil Biology Department Lomonosov Moscow State University (Moscow, Russian Federation)

Abstract. The article describes the taxonomic composition and photobionts localization specificities in aboveground lichens of the genus Cladonia. Moreover it analyzes the amount and algal species in thallus homogenates due to their age: in zones of active growth, aging zone and destruction zone; alga cells in washings from surface of thalli. Also the article analyzes the influence of the mycobiont on the photobiont species and abundance of the photobiont. It gives the comparison analysis of these data in lichens in the north taiga zone (Murmansk Region) and steppe zone (on the example of Orenburg Region). The method of direct microscopy helped to determine the taxonomic affiliation of the photobionts to the genus. Here the authors mean the size, shape of the cells, the nature of the chromatophore, etc. The number of photobionts in samples was studied both by light microscopy and fluorescence microscopy. The paper presents the comparison results of the amount and algae diversity in in the thalli of the above-ground lichens of the genus Cladonia due to their geographical location and the specificity of the age dynamics of the podecium. The research shows the fact that Asterochloris alga was the dominant group in the actively growing lichen podecia. However geographical location is not important. Chlorella, Stichococcus, Pseudococcomyxa were found in lichens algae. The authors believe that the new information about the changes in the taxonomic composition of algae, due to the age of the thallus is important for science. Pseudococcomyxa algae dominated in the old parts of the north taiga lichens and Stichococcus dominated in the steppe areas. Moreover the authors give the attempt of resynthesize lichen tallium from previously isolated cultures of the mycobiotic and photobiont. This attempt was unsuccessful at the period of the research work.

Keywords: symbiotic organisms; photobiont; Asterochloris; Stichococcus; Chlorella; Pseudococcomyxa; microbial communities of lichens; taxonomic structure of symbiosis; dynamics of algal abundance; north-taiga zone; steppe zone; BBS MSU; Murmansk Region; Orenburg Region. 